\title{
Pengaruh Takaran Pupuk Guano dan Biochar terhadap Pertumbuhan dan Hasil Tanaman Kacang Merah (Phaseolus vulgaris, L.) di Lahan Kering pada Dataran Menengah
}

\author{
Patrisius Naben ${ }^{a}$ dan Krisantus Tri Pambudi Raharjo ${ }^{b}$ \\ ${ }^{a}$ Fakultas Pertanian, Universitas Timor, Kefamenanu, TTU - NTT, Indonesia. \\ ${ }^{b}$ Fakultas Pertanian, Universitas Timor, Kefamenanu, TTU - NTT, Indonesia.
}

\section{Article Info}

Article history:

Received 1 Juni 2017

Received in revised form 22 Juni 2017

Accepted 9 Agustus 2017

\section{Keywords:}

Biochar

Guano

Kacang Merah

\section{Abstrak}

Penelitian dilaksanakan untuk mengetahui pengaruh takaran pupuk guano dan biochar terhadap pertumbuhan dan hasil tanaman kacang merah (Phaseolus vulgaris, L.) pada dataran menengah, di kebun percobaan Faperta Universitas Timor pada bulan Februari - April 2017, menggunakan Rancangan Acak Kelompok faktorial 3 x 3 diulang 3 kali. Faktor pertama takaran guano yang terdiri dari 3 taraf yaitu tanpa guano, guano $5 \mathrm{t} / \mathrm{ha}$ dan guano $10 \mathrm{t} / \mathrm{ha}$ sedangkan faktor kedua takaran biochar yang terdiri dari 3 taraf yaitu tanpa biochar, biochar $5 \mathrm{t} / \mathrm{ha}$ dan biochar $10 \mathrm{t} / \mathrm{ha}$. Hasil penelitian menunjukkan tidak terjadi interaksi antara aplikasi pupuk guano dengan biochar. Pemberian guano 10 t/ha secara nyata meningkatkan kadar lengas tanah $(17,62 \%)$, luas daun $\left(8.595 \mathrm{~cm}^{2}\right)$, jumlah bintil akar $(175,11)$, bobot kering akar $(0,70 \mathrm{~g})$, rasio tajuk akar $(16,24)$, jumlah polong pertanaman $(2,86)$, jumlah biji per polong $(2,86)$, bobot kering biji $(7,24 \mathrm{~g})$ dan bobot biji per petak $(1,17 \mathrm{t} / \mathrm{ha}$ ) dengan presentase peningkatan hasil sebesar $(31,1 \%)$. Peningkatan level pemberian Biochar tidak menunjukkan beda nyata antar level perlakuan, tetapi cenderung meningkatkan pertumbuhan dan hasil tanaman. @2017 dipublikasikan oleh Savana Cendana.

\section{Pendahuluan}

Kabupaten Timor Tengah Utara (TTU) memiliki banyak potensi pangan lokal diantaranya dari jenis kacang-kacangan. Kacang-kacangan loka merupakan alternatif sumber protein nabati yang murah dan terjangkau oleh masyarakat. Potensi kacang-kacangan tersebut belum sepenuhnya tergali, salah satunya adalah kacang merah (Phaseolus vulgaris, L.). Kacang merah memilki nilai jual cukup tinggi karena memiliki kandungan gizi yang tinggi terutama protein.

Produksi kacang merah di TTU berfluktuasi dari tahun ke tahun, data Badan Pusat Statistik menunjukkan bahwa produksi kacang merah di TTU pada tahun 2008 adalah 135 ton sementara pada tahun 2009 menurun menjadi 40 ton dan tahun 2010 menjadi 30 ton (BPS, 2011). Penurunan hasil tersebut diduga karena unsur hara yang dibutuhkan tanaman sangat minim, perubahan iklim khususnya curah hujan atau pertumbuhan awal tanaman yang mendapat gangguan serangan hama dan penyakit. Usaha pemberian nutrisi melalui pemupukan dan berbagai cara perlu dilakukan untuk memperbaiki proses pertumbuhan dan produks sangat dibutuhkan petani (Winaya, 1975; Harjadi, 1983). Penurunan hasi mengakibatkan ketersediannya dipasaran lokal rendah, diikuti kebutuhan oleh konsumen yang tinggi, menyebabkan harganya relative tinggi. Hal lain yang menghambat peningkatan produksi tanaman kacang merah adalah masyarakat di sekitar dataran menengah berasumsi bahwa tanaman kacang merah hanya dapat dibudidayakan pada dataran tinggi yang berhawa sejuk. Namun demikian Fachruddin (2000) melaporkan bahwa, tanaman ini masih dapat tumbuh pada ketinggian antara 500-600 m dpl dengan curah hujan yang baik untuk tanaman kacang merah adalah $1.500-2.500 \mathrm{~mm} /$ tahun. Oleh karenanya budidaya kacang merah di dataran dengan ketinggian menengah seperti sekitar kefamenanu diduga dapat menjadi alternatif dalam meningkatkan produksinya.

Pemanfaatan teknologi tepat guna seperti pemupukan dan pemberian biochar adalah salah satu solusi yang tepat, guna meningkatkan produks tanaman kacang merah di dataran menengah. Pertumbuhan tanaman yang baik memerlukan unsur hara yang cukup selama pertumbuhan sejak perkecambahan sampai menjelang panen. Ketersediaan hara yang cukup dan seimbang bag tanaman memungkinkan tanaman tumbuh dengan baik sehingga memberikan hasil yang baik pula.

Biochar merupakan arang hayati dari sebuah pembakaran tidak sempurna sehingga menyisakan unsur hara yang dapat menyuburkan lahan. Jika pembakaran berlangsung sempurna, biochar berubah menjadi abu dan melepaskan karbon yang nilainya lebih rendah (Gani, 2010). Proses pembuatan biochar bisa dilakukan secara tradisional, dimana hasil biocharnya dapa digunakan sebagai amandemen tanah (Lehmann \& Joseph, 2009). Menuru Lehmann \& Rondon (2006), pada percobaan laboratorium dan kegiatan komersial sekitar 54\% dari karbon yang ada dalam bahan dasar ditemukan dalam biochar, sedangkan dengan menggunakan peralatan sederhana hanya ditemukan $30-40 \%$

Menurut Lehmann (2007), semua bahan organik yang ditambahkan ke dalam tanah nyata meningkatkan berbagai fungsi tanah tak terkecuali retens berbagai unsur hara esensial bagi pertumbuhan tanaman. Biochar dilaporkan lebih efektif menahan unsur hara untuk ketersediaannya bagi tanaman dibandingkan bahan organik lain seperti sampah dedaunan, kompos atau pupuk kandang (Gani, 2009). Biochar juga menahan P, yang tidak bisa diretensi oleh bahan organik tanah biasa (Lehmann, 2007). Dua hal utama yang menjadi potensi biochar di bidang pertanian adalah afinitasnya yang tinggi terhadap unsur hara dan persistensinya. Biochar lebih persisten dalam tanah, sehingga semua manfaat yang berhubungan dengan retensi hara dan kesuburan tanah dapat berjalan lebih lama dibanding kandungan bahan organik lain yang biasa diberikan. Persistens yang lama menjadikan biochar pilihan utama untuk mengurangi dampak perubahan iklim. Walaupun dapat menjadi sumber energi alternatif, manfaa biochar jauh lebih besar jika dibenamkan ke dalam tanah dalam mewujudkan pertanian ramah lingkungan (Gani, 2010).

Lehmann et al. (2003) dengan penelitian pot menggunakan tanaman kacang tunggak (Vigna unguiculata (L.) Walp.) dan padi (Oryza sativa L.) menyimpulkan bahwa penambahan biochar nyata meningkatkan pertumbuhan dan nutrisi tanaman. Selanjutnya Nurida, (2010) dalam penelitiannya menyebutkan pemberian biochar dengan dosis 2,5 t/ha menunjukkan perbedaan tinggi tanaman sebesar 39,7 - 69\%. Hasil penelitian yang dilakukan oleh Masuli, (2010) pemberian biochar 10 t/ha meningkatkan jumlah anakan padi dengan ratarata jumlah anakan 17,33 serta meningkatkan total biomasa kering padi sebesar 75,93 g. Beberapa penelitian juga menunjukkan bahwa tingkat aplikasi biochar yang rendah memberikan hasil yang positif terhadap pertumbuhan tanaman yang dibudidayakan (Hunt et al., 2010).

Tujuan dari penelitian ini adalah untuk mengetahui pengaruh takaran pupuk guano dan biochar terhadap pertumbuhan dan hasil tanaman kacang merah di dataran menengah dan untuk memperoleh takaran pupuk guano dan biochar yang paling optimal meningkatkan pertumbuhan dan hasil tanaman kacang merah di dataran menengah

\section{Metode}

Penelitian ini dilaksanakan pada bulan Februari 2017 sampai April 2017 di kebun percobaan Fakultas Pertanian, belakang Perpustakaan, Universitas Timor, Kelurahan Sasi, Kecamatan Kota Kefamenanu, Kabupaten TTU. Percobaan lapangan menggunakan Rancangan Acak Kelompok (RAK) Faktorial yang terdiri dari dua faktor perlakuan, yaitu: faktor pertama pemberian Pupuk Guano (G) dengan tiga taraf, yaitu: $\mathrm{g}_{0}=$ Tanpa Guano (Kontrol), $\mathrm{g}_{1}=$ Guano 5 t/ha, $\mathrm{g}_{2}=$ Guano 10 t/ha; faktor kedua pemberian Biochar (A) dengan tiga taraf, yaitu: $\mathrm{a}_{0}=$ Tanpa biochar (kontrol), $\mathrm{a}_{1}=$ Biochar $5 \mathrm{t} / \mathrm{ha}, \mathrm{a}_{2}=$ Biochar $10 \mathrm{t} / \mathrm{ha}$.

Pelaksanaan penelitian ini diawali dengan Persiapan Benih kacang merah yang diperoleh dari petani di Eban, Kecamatan Miomaffo Barat. Pengolahan tanah dilakukan dengan cara mencangkul, membersihkan dari gulma, penggemburan tanah, pembuatan bedengan atau petak percobaan dengan ukuran panjang $120 \mathrm{~cm} \times 120 \mathrm{~cm}$. Jarak antar ulangan $50 \mathrm{~cm}$ dan jarak antar petak 30 $\mathrm{cm}$. Penempatan perlakuan dilakukan dalam dua tahap. Tahap pertama adalah pengacakan antara blok atau kelompok perlakuan. Tahap kedua pengacakan terhadap perlakuan dalam tiap blok. Biochar yang digunakan dalam penelitian ini adalah hasil dari pembakaran beberapa jenis kayu dimana arang kayu tersebut diperoleh dari sisa-sisa proses pembuatan batu merah

Pemberian pupuk dan biochar dilakukan secara bertahap namun pada hari yang sama yaitu pembenaman pupuk di semua petak percobaan lalu diikut dengan pembenaman biochar sesuai dosis perlakuan di semua petak yang telah teracak disetiap blok. Setelah pembenaman, dibiarkan (inkubasi) selama 2 minggu dengan tujuan agar mengurangi aktifitas mikroorganisme yang terdapa pada pupuk yang diberikan pada setiap petak percobaan selain kontrol.

Penanaman dilakukan 2 minggu setelah aplikasi pupuk dan biochar dengan menggunakan tugal pada jarak tanam $20 \times 20 \mathrm{~cm}$ dengan 2 biji perlubang tanam. Pemeliharaan Tanaman meliputi: 1) Penyiraman yang dilakukan 1-2 kali dalam sehari yaitu pagi dan sore, 2) Penyulaman dilakukan bila ada tanaman yang mati atau tidak tumbuh, 3) Penyiangan, pengendalian hama dan penyakit (bila terserang). Kacang merah dipanen pada umur 70 HST, ciri-ciri fisiknya adalah $90 \%$ daun menguning bahkan kering karena jika Biji kacang merah yang dipetik sebelum tua (masak fisiologis) memiliki kualitas yang rendah (biji mudah keriput)

Pengamatan meliputi; suhu tanah, kadar lengas tanah, $\mathrm{pH}$ tanah, DHL (daya hantar listrik) tanah, tinggi tanaman, jumlah daun, diameter batang, jumlah tangkai produktif, luas daun, jumlah bintil akar, panjang akar, berat segar akar, bobot kering akar, rasio tajuk akar, berat segar tanaman (vegetatif maksimum), berat kering tanaman (vegetatif maksimum), rasio tajuk akar, jumlah polong per tanaman, jumlah biji per polong, berat biji (panen), berat kering biji, berat 100 biji, berat biji per petak.

Data hasil pengamatan kemudian dianalisis dengan menggunakan sidik ragam (Anova) RAK faktorial. Rata-rata perlakuan selanjutnya diuji lanjut dengan menggunakan Duncan Multiple Range Test (DMRT) dengan tingkat signifikan 5\% sesuai petunjuk Gomez \& Gomez (1995). Analisis data menggunakan program SAS 9.1 
3. Hasil dan Pembahasan

\subsection{Hasil Pengamatan}

Hasil sidik ragam (Anova) menunjukkan bahwa tidak terjadi interaksi antara perlakuan takaran pupuk guano dan biochar terhadap pertumbuhan kacang merah di dataran menengah. Takaran pupuk guano $10 \mathrm{t} / \mathrm{ha}$ mengakibatkan kondisi lingkungan tanaman; suhu tanah terendah kadar lengas tanah tertinggi, DHL tanah tertinggi dan $\mathrm{pH}$ tanah lebih rendah dibanding level perlakuan lainnya, sedangkan biochar tidak menunjukkan beda nyata namun pada level pemberian yang berbeda, dapat meningkatkan pertumbuhan dan hasil tanaman.

Tabel 1. Suhu Tanah $\left({ }^{\circ} \mathrm{C}\right)$, Kadar Lengas (\%), DHL Tanah dan pH Tanah.

\begin{tabular}{|c|c|c|c|c|c|c|c|}
\hline \multirow{2}{*}{ Perlakuan } & \multicolumn{4}{|c|}{ Suhu Tanah } & \multirow{2}{*}{ Kadar Lengas } & \multirow{2}{*}{$\begin{array}{c}\text { Daya Hantar } \\
\text { Listrik }\end{array}$} & \multirow{2}{*}{$\mathrm{pH}$} \\
\hline & $15 \mathrm{HST}$ & $30 \mathrm{HST}$ & $45 \mathrm{HST}$ & $60 \mathrm{HST}$ & & & \\
\hline \multicolumn{8}{|l|}{ Takaran Guano (t/ha) } \\
\hline 0 & $30,67 \mathrm{~b}$ & $31,44 \mathrm{a}$ & $30,61 \mathrm{a}$ & $29,31 \mathrm{a}$ & $14,90 \mathrm{~b}$ & $205,89 \mathrm{a}$ & $8,36 \mathrm{a}$ \\
\hline 5 & $31,51 \mathrm{a}$ & $30,11 \mathrm{~b}$ & $29,39 \mathrm{~b}$ & $29,81 \mathrm{a}$ & $15,71 \mathrm{~b}$ & $202,56 \mathrm{a}$ & $8,13 \mathrm{~b}$ \\
\hline 10 & $30,91 \mathrm{~b}$ & $29,22 \mathrm{~b}$ & $28,59 \mathrm{c}$ & $28,55 \mathrm{a}$ & $17,62 \mathrm{a}$ & $260,78 \mathrm{a}$ & $8,12 \mathrm{~b}$ \\
\hline \multicolumn{8}{|l|}{ Takaran Biochar (t/ha) } \\
\hline 0 & $31,01 \mathrm{a}$ & $30,33 \mathrm{a}$ & $29,29 \mathrm{a}$ & $29,20 \mathrm{a}$ & $14,86 \mathrm{a}$ & $224,56 \mathrm{a}$ & $8,29 \mathrm{a}$ \\
\hline 5 & $31,09 \mathrm{a}$ & $30,36 \mathrm{a}$ & $29,24 \mathrm{a}$ & $29,24 \mathrm{a}$ & $16,61 \mathrm{a}$ & $219,11 \mathrm{a}$ & $8,21 \mathrm{ab}$ \\
\hline 10 & $30,99 \mathrm{a}$ & $30,09 \mathrm{a}$ & $29,87 \mathrm{a}$ & $29,82 \mathrm{a}$ & $16,76 \mathrm{a}$ & $225,56 \mathrm{a}$ & $8,12 \mathrm{~b}$ \\
\hline
\end{tabular}

Kondisi lingkungan dalam penelitian ini berdampak pada pertumbuhan tanaman, pengaruh utama takaran pupuk guano 10 t/ha menghasilkan pertumbuhan; tinggi tanaman $(33,44 \mathrm{~cm})$, jumlah daun terbanyak $(39,30$ helai), diameter batang $(0,80 \mathrm{~cm})$, jumlah tangkai $\left(10,87\right.$ tangkai), luas daun $\left(8.595 \mathrm{~cm}^{2}\right)$ dan jumlah bintil akar $(175,11)$ yang umum berbeda nyata dibanding leve perlakuan lainnya. Demikian pula pemberian biochar tidak menunjukkan beda nyata namun pada level pemberian yang berbeda dapat meningkatkan pertumbuhan tanaman.

Tabel 2. Rerata Tinggi Tanaman (cm), Diameter Batang (mm), Jumlah Daun, Jumlah Tangkai, Luas Daun $\left(\mathrm{cm}^{2}\right)$ dan Jumlah Bintil Akar.

\begin{tabular}{|c|c|c|c|c|c|c|}
\hline \multirow{2}{*}{ Perlakuan } & \multicolumn{4}{|c|}{ Rata-Rata Pengukuran 60 HST } & \multirow{2}{*}{ Luas Daun } & \multirow{2}{*}{ Jumlah Bintil Akar } \\
\hline & Tinggi Tanaman & Diameter Batang & Jumlah Daun & Jumlah Tangkai & & \\
\hline \multicolumn{7}{|c|}{ Takaran Guano (t/ha) } \\
\hline 0 & $20,95 \mathrm{c}$ & $0,59 \mathrm{c}$ & $23,02 \mathrm{~b}$ & $6,56 \mathrm{~b}$ & $5.659 \mathrm{~b}$ & $116,00 \mathrm{~b}$ \\
\hline 5 & $28,66 \mathrm{~b}$ & $0,69 \mathrm{~b}$ & $27,19 \mathrm{~b}$ & $7,59 \mathrm{~b}$ & $7.755 \mathrm{a}$ & $112,56 \mathrm{~b}$ \\
\hline 10 & $33,44 \mathrm{a}$ & $0,80 \mathrm{a}$ & $39,30 \mathrm{a}$ & $10,87 \mathrm{a}$ & $8.595 \mathrm{a}$ & $175,11 \mathrm{a}$ \\
\hline \multicolumn{7}{|c|}{ Takaran Biochar (t/ha) } \\
\hline 0 & $27,85 \mathrm{a}$ & $0,70 \mathrm{a}$ & $28,87 \mathrm{a}$ & $8,13 \mathrm{a}$ & $7.136 \mathrm{a}$ & $122,22 \mathrm{a}$ \\
\hline 5 & $26,60 \mathrm{a}$ & $0,70 \mathrm{a}$ & 30,39 a & $8,30 \mathrm{a}$ & $6.958 \mathrm{a}$ & $129,89 \mathrm{a}$ \\
\hline 10 & $28,60 \mathrm{a}$ & $0,69 \mathrm{a}$ & $30,24 \mathrm{a}$ & $8,59 \mathrm{a}$ & $7.915 \mathrm{a}$ & $151,56 \mathrm{a}$ \\
\hline
\end{tabular}

Keterangan: Angka pada baris dan kolom diikuti huruf sama tidak berbeda pada taraf nyata $(\alpha) 5 \%$ menurut uji DMRT.

Meskipun kondisi lingkungan di atas mendukung pertumbuhan tanaman, Leopold \& Kriedermann, (1975) melaporkan bahwa pertumbuhan tanaman membutuhkan ukuran yang secara tepat dapat dibaca dengan bentuk kuantitatif yang dapat diukur. Pertumbuhan tanaman dapat diukur tanpa mengganggu tanaman yaitu dengan parameter pengukuran tinggi tanaman, jumlah daun, jumlah tangkai, panjang akar, bobot segar dan sebagainya namun kurang mencerminkan ketelitian kuantitatif. Lebih lanjut dikemukakan oleh
Goldsworthy \& Fisher (1992) bahwa berat basah suatu tanaman sangat dipengaruhi oleh status air, dimana tanaman kacang merah dengan takaran guano $10 \mathrm{t} /$ ha memiliki bobot akar $(3,44 \mathrm{~g})$, berat segar tanaman (vegetatif maksimum) $(40,96 \mathrm{~g})$, berat segar berangkasan $(710,00 \mathrm{~g})$ dan berat segar biji $(20,70 \mathrm{~g})$, berbeda nyata dibanding pemberian pada takaran $5 \mathrm{t} / \mathrm{ha}$ dan kontrol. Pengaruh utama biochar tidak menunjukkan beda nyata antar level perlakuan, namun peningkatan level pemberian cenderung meningkatkan berat segar tanaman.

Tabel 3. Akumulasi Bobot Segar Tanaman Kacang Merah (Bobot Segar Akar, Bobot Segar Tanaman, Bobot Segar Berangkasan dan Bobot Biji)

\begin{tabular}{|c|c|c|c|c|}
\hline \multirow{2}{*}{ Perlakuan } & \multicolumn{4}{|c|}{ Rata-Rata Akumulasi Bobot Segar } \\
\hline & Bobot Segar Akar & Bobot Segar Tanaman & Bobot Segar Berangkasan & Bobot Segar Biji \\
\hline \multicolumn{5}{|l|}{ Takaran Guano (t/ha) } \\
\hline Kontrol & $2,58 \mathrm{a}$ & $19,68 \mathrm{c}$ & $330,00 \mathrm{c}$ & $17,82 \mathrm{~b}$ \\
\hline 5 & $2,63 \mathrm{a}$ & $31,08 \mathrm{~b}$ & $466,67 \mathrm{~b}$ & $18,81 \mathrm{~b}$ \\
\hline 10 & $3,44 \mathrm{a}$ & $40,96 \mathrm{a}$ & $710,00 \mathrm{a}$ & $20,70 \mathrm{a}$ \\
\hline \multicolumn{5}{|l|}{ Takaran Biochar (t/ha) } \\
\hline Kontrol & $2,87 \mathrm{a}$ & $33,40 \mathrm{a}$ & $465,56 \mathrm{a}$ & $19,00 \mathrm{a}$ \\
\hline 5 & $2,87 \mathrm{a}$ & 29,25 a & $502,22 \mathrm{a}$ & $18,59 \mathrm{a}$ \\
\hline 10 & $2,91 \mathrm{a}$ & $29,07 \mathrm{a}$ & 538,89 a & $19,74 \mathrm{a}$ \\
\hline
\end{tabular}

Status air suatu jaringan atau keseluruan tubuh tanaman dapat berubah seiring pertambahan umur tanaman dan dipengaruhi oleh lingkungan yang jarang konstan sehingga pengukuran berat kering lebih disukai karena tidak dipengaruhi oleh status air suatu tumbuhan. Pengukuran berat kering merupakan bagian dari pengukuran biomasa tumbuhan. Biomasa tanaman adalah ukuran yang paling sering digunakan untuk mendeskripsi dan mengetahui pertumbuhan suatu tanaman karena biomassa tanaman merupakan gabungan dari hampir semua peristiwa yang dialami oleh suatu tanaman selama siklus hidupnya (Sitompul \& Guritno, 1995).

Tabel 4. Akumulasi Berat Kering \{Berat Kering Akar (g), Rasio Tajuk Akar, Berat Kering Tanaman (g), Berat Kering Berangkasan (g), Berat Biji Kering (g), Berat 100 Biji (g) dan Berat Biji Per Petak (t/ha)\}

\begin{tabular}{|c|c|c|c|c|c|c|c|}
\hline \multirow[b]{2}{*}{ Perlakuan } & \multicolumn{7}{|c|}{ Rata-Rata Akumulasi Berat Kering } \\
\hline & $\begin{array}{c}\text { Bobot Kering } \\
\text { Akar }\end{array}$ & $\begin{array}{c}\text { Rasio Tajuk } \\
\text { Akar }\end{array}$ & $\begin{array}{c}\text { Bobot Kering } \\
\text { Tanaman }\end{array}$ & $\begin{array}{c}\text { Bbobot Kering } \\
\text { Berangkasan }\end{array}$ & $\begin{array}{l}\text { Bobot Biji } \\
\text { Kering }\end{array}$ & $\begin{array}{c}\text { Bobot } 100 \\
\text { Biji }\end{array}$ & Bobot Biji/Petak \\
\hline Takaran Guano (t/ha) & & & & & & & \\
\hline 0 & $0,46 \mathrm{~b}$ & $10,63 \mathrm{~b}$ & $4,74 \mathrm{c}$ & $82,74 \mathrm{c}$ & $4,93 \mathrm{~b}$ & $22,21 \mathrm{a}$ & $0,89 \mathrm{~b}$ \\
\hline 5 & $0,55 \mathrm{~b}$ & $15,40 \mathrm{a}$ & $8,11 \mathrm{~b}$ & $114,35 \mathrm{~b}$ & $6,32 \mathrm{a}$ & $22,31 \mathrm{a}$ & $1,16 \mathrm{a}$ \\
\hline 10 & $0,70 \mathrm{a}$ & $16,24 \mathrm{a}$ & $10,45 \mathrm{a}$ & $175,29 \mathrm{a}$ & $7,24 \mathrm{a}$ & $22,79 \mathrm{a}$ & $1,17 \mathrm{a}$ \\
\hline Takaran Biochar (t/ha) & & & & & & & \\
\hline 0 & $0,64 \mathrm{a}$ & $13,48 \mathrm{a}$ & $8,53 \mathrm{a}$ & $115,17 \mathrm{a}$ & $6,15 \mathrm{a}$ & $22,21 \mathrm{a}$ & $1,00 \mathrm{a}$ \\
\hline 5 & $0,57 \mathrm{ab}$ & $12,50 \mathrm{a}$ & $7,12 \mathrm{a}$ & $125,45 \mathrm{a}$ & $5,63 \mathrm{a}$ & $22,14 \mathrm{a}$ & $1,06 \mathrm{a}$ \\
\hline 10 & $0,49 \mathrm{~b}$ & $16,29 \mathrm{a}$ & $7,65 \mathrm{a}$ & $131,75 \mathrm{a}$ & $6,71 \mathrm{a}$ & $22,96 \mathrm{a}$ & $1,17 \mathrm{a}$ \\
\hline
\end{tabular}

Keterangan: Angka pada baris dan kolom diikuti huruf sama tidak berbeda pada taraf nyata $(\alpha) 5 \%$ menurut uji DMRT. 
Selanjutnya, Leopold \& Kriedermann, (1975) membuktikan bahwa akumulasi bahan kering sangat disukai sebagai ukuran pertumbuhan. Akumulasi bahan kering mencerminkan kemampuan tanaman dalam mengikat energi dari cahaya matahari melalui proses fotosintesis serta interaksinya dengan faktor lingkungan lainnya. Distribusi akumulasi bahan kering pada bagian-bagian tanaman seperti akar, batang, daun dan bagian generatif dapat mencerminkan produktivitas tanaman. Dari penelitian di dataran menengah ini, tanaman kacang merah yang diberi pupuk guano dengan takaran $10 \mathrm{t} / \mathrm{ha}$ menghasilkan, berat kering akar $(0,70 \mathrm{~g})$, berat kering tanaman $(10,45 \mathrm{~g})$, berat biji kering $(7,24 \mathrm{~g})$, berat 100 biji $(22,79 \mathrm{~g})$ dan berat biji per petak $(1,17 \mathrm{t} / \mathrm{ha})$ yang berbeda nyata dengan pemberian guano 5 t/ha dan kontrol. Demikian pula pemberian biochar tidak menunjukkan beda nyata namun pada level pemberian yang berbeda cenderung meningkatkan hasil tanaman. Pemberian guano 10 t/ha menghasilkan pertumbuhan yang maksimal berhubungan erat dengan rasio tajuk akar yang lebih tinggi 16,24 ini sesuai dengan hasil yang dilaporkan sebelumnya, bahwa pertumbuhan tajuk lebih ekstensif apabila faktor nitrogen (N) (Murata, 1969) dan air (Loomis, 1953) tersedia dalam keadaan yang cukup (opimal).

\subsection{Pembahasan}

Penanaman kacang merah di dataran menengah dengan takaran guano dan biochar dalam penelitian ini tidak terjadi interaksi antar perlakuan. Pengaruh utama takaran pupuk guano $10 \mathrm{t} /$ ha mengakibatkan kondisi lingkungan tanaman, suhu tanah terendah, kadar lengas tanah tertinggi, DHL tanah tertinggi, dan $\mathrm{pH}$ tanah lebih rendah dibanding level perlakuan lainnya. Demikian pula pengaruh utama biochar tidak menunjukkan beda nyata antar level perlakuan, namun peningkatan level pemberian 10 t/ha mengakibatkan kondisi lingkungan tanaman, suhu tanah terendah, kadar lengas tanah tertinggi, DHL tanah tertinggi, $\mathrm{pH}$ lebih rendah dibanding level perlakuan lainnya.

Kondisi lingkungan tersebut berdampak pada pertumbuhan tanaman, pengaruh utama takaran pupuk guano 10 t/ha menghasilkan pertumbuhan; tinggi tanaman $(33,44 \mathrm{~cm})$, jumlah daun terbanyak (39,30 helai), Diameter batang $(0,80$ $\mathrm{cm})$, jumlah tangkai $\left(10,87\right.$ tangkai), luas daun $\left(8.595 \mathrm{~cm}^{2}\right)$ dan jumlah bintil akar $(175,11)$ yang umum berbeda nyata dibanding level perlakuan lainnya. Pemberian guano $10 \mathrm{t} / \mathrm{ha}$ menghasilkan pertumbuhan yang maksimal berhubungan erat dengan rasio tajuk akar yang lebih tinggi 16,24 ini sesuai dengan hasil yang dilaporkan sebelumnya, bahwa pertumbuhan tajuk lebih ekstensif apabila faktor nitrogen (N) (Murata, 1969) dan air (Loomis, 1953) tersedia dalam keadaan yang cukup (opimal).

Hasil tanaman kacang merah dalam penelitian ini yang diberi pupuk guano dengan takaran 10 t/ha di dataran menengah memperoleh bobot biji kering $(7,24$ $\mathrm{g})$, bobot $100 \mathrm{biji}(22,79 \mathrm{~g})$ dan bobot biji per petak $(1,17 \mathrm{t} / \mathrm{ha})$ dengan presentase peningkatan hasil sebesar $(31,1 \%)$ yang berbeda nyata dengan pemberian guano $5 \mathrm{t} /$ ha dan kontrol. Demikian pula pemberian biochar tidak menunjukkan beda nyata namun pada level pemberian yang berbeda dapat meningkatkan hasil tanaman.

\section{Simpulan}

Tidak terjadi interaksi antara pemberian guano dan biochar, namun takaran guano 10 t/ha dapat meningkatkan presentase hasil sebesar $31,1 \%$ yang berbeda nyata dibanding dibanding pemberian 5 t/ha dan kontrol. Demikian pula pengaruh utama biochar tidak menunjukkan beda nyata antar level perlakuan, namun peningkatan level pemberian $10 \mathrm{t} / \mathrm{ha}$ mengakibatkan kondisi lingkungan tanaman dan kondisi pertumbuhan maupun hasil tanaman meningkat.

\section{Pustaka}

Badan Pusat Statistik Kabupaten Timor Tengah Utara. 2011. Timor Tengah Utara Dalam Angka. Kefamenanu.

Fachruddin, L. 2000. Budidaya Kacang-kacangan. Kanisius, Jakarta

Gani, A. 2009. Biochar Penyelamat Lingkungan. Balai Besar Penelitian Tanaman Padi. Warta Penelitian dan Pengembangan Pertanian. Vol 31. No.6, 2009.

Gani. 2010. Potensi Arang Hayati Biochar sebagai Komponen Teknologi Perbaikan Produktivitas Lahan Pertanian. Jurnal Iptek Tanaman Pangan Vol. 4 No. 1 - 2009.

Goldsworthy, P. R dan N. M. Fisher. 1992. Fisiologi TanamanBudidaya Tropik (terjemahan). Gadjah Mada University Press. Yogyakarta, hal 295.

Gomez, K. A. and Gomez, A. A. 1995. Prosedur Statistik Untuk Penelitian Pertanian. Edisi ke 2. UI Press: Jakarta.

Harjadi, S.S., 1983. Pengantar Agronomi. : PT Gramedia Jakarta

Hunt J. M. DuPonte, D. Sato, A. Kawabata. 2010. The Basics of Biochar: A Natural Soil Amendment. Colege Tropical Agriculture and Human Resources University of Hawai'i at Manoa, Honolulu, Hawaii. J. Soil and Crop Management Dec. 2010 SCM-30.

Lehmann, J., J.P. da Silva Jr., C. Steiner, T. Nehls, W. Zech, and B. Glaser. 2003. Nutrient availability and leaching in an archaeological Anthrosol and a Ferralsol of the Central Amazon basin: fertilizer, manure and charcoal amendments. Plant and Soil 249:343-357.

Lehmann, J. and M. Rondon. 2006. Biochar soil management on highly weathered soils in the humid tropics. p: 51 7-530 In Biological Approaches to Sustainable Soil Systems (Norman Uphoff et al Eds.). Taylor \& Francis Group PO Box 409267 Atlanta, GA 30384-9267.

Lehmann, J. 2007. Bioenergy in the black. Frontiers in Ecology and then Environment 5: $381-387$.
Lehmann, J. and S. Joseph. 2009. Biochar for environmental management: an introduction. science and technology. In: Lehmann and Joseph (Eds.). First published by Earthscan in the UK and USA in 2009.

Leopold, A. C and P. E Kriedemann. 1975. Plant Growt and Development. Tata Mc Grow Hill Pub. Co. Ltd., New Delhi. 545p.

Loomis, W.E. 1953. Growth and Differentiation in Plants. Ames: Lowa State College Press.

Masuli A. 2010. Rice Husk Biochar for Rice Based Cropping System in Acid Soil 1. The Characteristics of Rice Husk Biochar and Its Influence on the Properties of Acid Sulfate Soils and Rice Growth in West Kalimantan, Indonesia. J. Agriculturan Science. Vol. 2 No.1.

Murata, Y. 1969. In Physiologycal Aspect of Crop Yield, editor J. D. Eastin et al., Madison,Wis. : American Society of Agronomy.

Nurida N.L., 2010. Potensi Biochar Limbah Pertanian sebagai Pembenah Tanah untuk Meningkatkan Kualitas Tanah. Workshop Pemanfaatan Biochar. Kerjasama BPTP NAD dengan Australian Centre for International Agricultural Research (ACIAR). Balai Pengkajian Teknologi Pertanian Aceh (Aceh Assessment Institute for Agricultural Technology (AIAT))

Sitompul, S. M dan B. Guritno. 1995. Analisis Pertumbuhan Tanaman. Gadjah Mada University Press.Yogyakarta, hal. 24.

Winaya, D. 1975. Kesuburan Tanah dan Pupuk. Denpasar. Fakultas Pertanian Universitas Udayana.Denpasar. 